\title{
Towards sustainable capitalism in the development of higher education business school curricula and management
}

\author{
Peter Beusch \\ Business Administration \\ School of Business, Economics and Law, Gothenburg University \\ Gothenburg, Sweden \\ peter.beusch@handels.gu.se
}

A revised version of this article has been accepted by:

International Journal of Educational Management (2014, Vol. 28, Issue 5)

(Please do not yet copy without permission of author)

\begin{abstract}
Purpose - This article accounts for, and conceptualizes, the internal and external forces that influence higher education business schools as they strive to integrate sustainability issues into their curricula in the effort to achieve a more sustainable (yet capitalist) world.

Design/methodology/approach - A case study approach is used for the research, which is grounded in the relevant literature, to investigate sustainable development issues in the context of a Swedish business school (university level). The empirical data consists of a review of internal documents plus E-mail surveys and interviews and discussion seminars with university teachers/researchers and key administrators.
\end{abstract}

Findings - Two models are presented that map the various internal and external forces behind business schools' curriculum change. One important finding describes how supply and demand influences business schools and recruiters of business students.

Limitations - Because this research is based on a single case study, the analysis and the mapping in the article are somewhat limited in their general applicability. However, the research context of the business school permits drawing conclusions that may apply to a broad class of colleges or departments in higher education. In addition, because the research is supported by significant ideas from the literature, general inferences may be drawn about business school curricula.

Originality/value - The two tentative models provide a holistic framework that adds to our understanding of the composition and interrelationship of influential forces on business schools when major changes in curricula and their management are contemplated.

Keywords - Business school, business model, business school model, business school management, curriculum, higher education, sustainable development, sustainable capitalism

Article type - Conceptual, with a case study 


\section{Introduction}

The world today is changing rapidly and profoundly - economically, politically and socially (Lambert, 2012) and the capitalist system is under siege (Porter and Kramer, 2011). It seems more important than ever to educate future (and current) business students for managerial positions in this changing environment. This article addresses this challenge generally with a literature review of the related issues and problems, and specifically with its investigation of curriculum and management change at a Swedish university business school. In this setting, many academics, as well as practitioners, recognize that a crucial issue in business today is the idea of sustainability or sustainable development. ${ }^{1}$

Today, about $20 \%$ of the students worldwide who pursue undergraduate and/or graduate degrees enrol in higher education business schools (AACSB, 2013). In the United States, for example, business and management education in the new millennium is 'the largest single field in higher education' (Pfeffer and Fong, 2004, p. 1511). Some observers (e.g., Pfeffer and Fong, 2004; Starkey et al., 2004; Thomas and Cornuel, 2011) think the popularity of business studies is, to a large extent, the result of institutional rankings and statistics that show the future economic value of a degree in business. Such potential for economic payback, however, is not an automatic guarantee of the quality of the graduate's education.

Critics, in fact, charge that business schools, in particular MBA programmes, are irrelevant as far as the needs of practicing managers because they provide little benefit to their students or to companies and other organizations that employ them (Pfeffer and Fong, 2002; Mintzberg, 2004). Another, possibly even more serious, allegation is that business schools promote a "profits-first" mentality in their students (e.g., Ghoshal, 2005; Giacalone and Thompson, 2006). According to this allegation, this single-minded pursuit of profits, accompanied by the assumption of opportunism, may partly account for the numerous recent accounting scandals and unethical executive actions (e.g., Hailey, 1998; Henle, 2006).

Other observers, however, defend business schools. They claim, for example, that students who earn MBAs acquire a good education and therefore can have a positive impact on society. For example, Slater and Dixon-Fowler (2010, p. 429) conclude 'the future of the planet is in the hands of MBAs' as they find a clear and positive association between CEOs with MBA degrees and their companies' corporate environmental performance.

For many businesses as well as for business schools and leading business school associations (e.g. EMAS and AACSB), sustainability has become an increasingly important concern. To understand all this, one needs to look at the development of business school education since the 1950s as three major paradigm shifts are evident (Figure 1). The first shift occurred in the 1950s as a result of the reports sponsored by the Ford Foundation and the Carnegie Foundation on 'scientific rigor' and 'academic legitimacy' (Goodrick, 2002). Management and business education then changed from vocational training to a 'real' scientific activity (GRLI, 2013). Grounded in empirical research, this scientific approach (greater academic rigor) was intended to rationalize organizations' decision-making. In effect, this approach promoted and revolutionized business education worldwide.

In the second shift, which began in the late 1970s and continued in the 1980s and 1990s, neo-liberalism and ideological and governmental change (e.g. Thatcherism and Reaganomics as described in Larner, 2000) had a strong impact on (public) management. In these years, there was a fundamental change in business school education overall as intellectual bodies became performance centres (Olssen and Peters, 2005). Market fundamentalism 'took hold of business education' and financial results became the only focus with 'the company's stock price the primary barometer of success' (Holland, 2009, p. 2). New business models ${ }^{2}$, which replaced organizational and managerial rationalities, almost entirely focused on shareholder value and the logic of the markets. For example, the Capital Asset Pricing Model (CAPM), 
the Efficient Market Hypothesis (EMH), and various options pricing models helped revolutionize many organizations' ways of doing business (e.g., Hamel, 2001).

This new 'free market' focus, however, led to a distorted emphasis on profits and to serious accounting abuses, resulting in well-known business failures around the turn of the millennium (e.g., the bursting of the dot com bubble, the Enron scandal, the early $21^{\text {st }}$ century financial crisis, etc.). One explanation is that responsible executives, who had been trained in scientific technology, often lacked interpersonal skills, practical judgement and even moral foundations (Bennis and Toole, 2005).

In today's general debate about business school models and curricula development, one criticism in particular has received significant attention. The criticism is that the greatest world problem of our time is sustainability with its environmental, economic and social implications. The debate has initiated the third shift in business school education (e.g., Starkey et al., 2004; Giacalone and Thompson, 2006; Bradfield, 2009; Thomas and Cornuel, 2011) and in business itself (e.g., Porter and Kramer, 2011; Scherer et al., 2013).

This shift represents a new wave of change (Forray and Leigh, 2012). As a result, it has become necessary to re-think the purpose of, and justification for, business school education. Some commentators (e.g., Porter and Kramer, 2011) call for a revolution in society supported by business entities and business schools in which the focus is on both societal and organizational rationality.

Therefore, almost 70 years after the reports by the Ford Foundation and the Carnegie Foundation, many business schools have realized they must adapt their management education to meet the changing societal and economic demands for responsible resource stewardship. This adaptation means that business schools, which prepare students for employment in well-functioning organizations, must offer an education with both scientific rigor and societal relevance (Holland, 2009). For this paradigm shift to succeed, a new value proposition based on "responsible management education" (e.g., Forray and Leigh, 2012) is required.

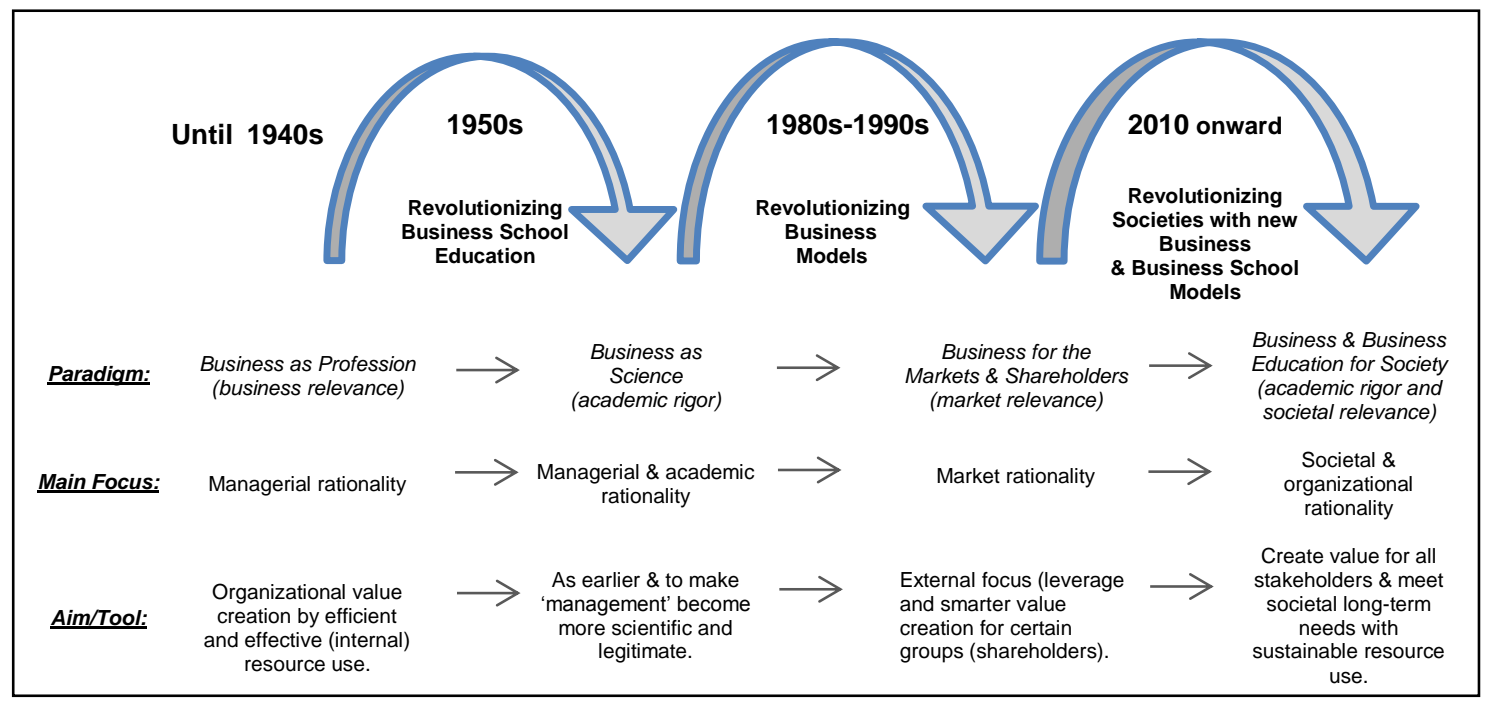

Figure 1: The three paradigm shifts in business school education and business model development

Sustainability is a complex issue that simultaneously involves many stakeholders. Perhaps this complexity explains why the sustainability debate has typically occurred separately in different institutions (e.g., business schools, companies, NGOs, etc.). In response to various criticisms of the isolated nature of this debate (e.g., Holland, 2009 and GRLI, 2013), this 
article extends the framework and looks at sustainability issues at the juncture of three important areas (Figure 2).

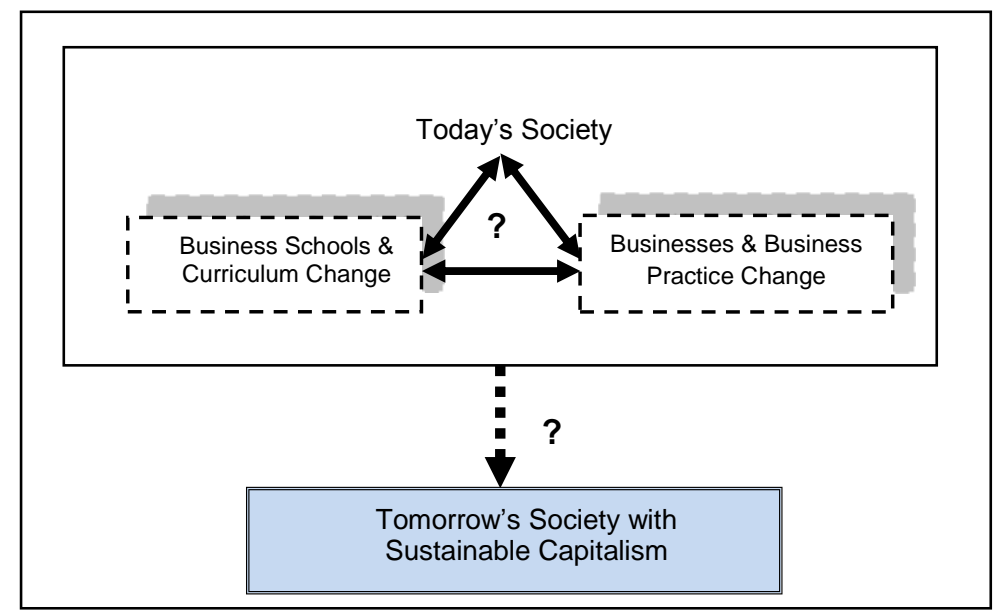

Figure 2: The research area of Business School Education \& Business Model Development

The first area relates to curriculum changes in contemporary business schools. The second area concerns possible changes in practices by business organizations. The third area is today's society in which these two institutions exist and evolve. Thus, the focus of this article is the intricate and interconnected relationship among these three areas as they reflect the concern with sustainability issues in the context of sustainable capitalism. This article therefore poses the following questions:

1) Which internal and external factors influence the integration of sustainability issues in business school curricula and in business practices?

2) What is required to change the existing curricula such that they support sustainable capitalism?

The remainder of this article is structured as follows. Sections 2, 3 and 4 review the theoretical and conceptual issues. Section 2 focuses on business schools in today's society. Section 3 addresses how business schools work with sustainable issues in their curricula. Section 4 is a discussion of the role of businesses, their business models and their practices. Thereafter, Sections 5, 6 and 7 examine the role of 'typical' business schools using the case study of Handels, a Swedish business school. Section 5 presents contextual and methodological issues. Section 6 (curriculum development at 'Handels') presents the results from a large survey, reviews of internal documents, an E-mail survey, and seminars and meetings. Section 7 deals with the intermediary role of the business school between the Market and the State. These three sections primarily illustrate the internal challenges business schools face. Section 8 (the external forces) and Section 9 (the internal forces) summarize and map the case study results, combined with insights from the literature, and present the two models developed from this research. Section 10 discusses the findings but also some limitations thereof. Section 11 concludes the article and provides suggestions for how business schools may move forward in the effort to add sustainability issues to their curricula as they work towards sustainable capitalism. 


\section{Business schools and society today}

Society seems to change in its attitude toward environmental problems. In many countries, particularly in Europe, more environmental legislation is being passed (e.g., new emission standards in the automotive and transportation industries). As a result, hitherto undreamed of environmentally friendly product improvements have been manufactured. Various other actions that reflect environmental and safety concerns have been taken. One example is Germany's announcement that it will close all its nuclear power plants by the year 2022 .

It has further been suggested that Gross Domestic Product (GDP) as a measure of the market value of goods and services could be replaced with a measure of human welfare that takes into consideration the sustainability of future production (e.g. in European Communities, 2009). Such a change, which would make sustainability the (business) solution of the future, is consistent with the opinions of some of the most well-known management thinkers of today (e.g., see Porter and Kramer, 2011).

Across the Atlantic, protests by the Occupy Wall Street movement have drawn attention to the perils in the current financial system (and possibly in the entire world order). This and similar evidence (described by, e.g., den Hond and de Bakker, 2007) suggest a paradigm shift in the attitude toward capitalism may be evolving. What effect that change, if it takes place, will have on business and employees is difficult to predict.

Somewhat different recommendations have been made in the hope that global wealth will still continue to increase. Acs and Phillips (2002), for example, think society is served best by an 'entrepreneurial capitalism' that relies on volunteerism, private foundations, and 'giving back to society' (by philanthropists such as Rockefeller, Soros, Turner and Gates). Seelos and Mair (2005) and Martin and Osberg (2007) describe the necessity for more 'social entrepreneurs', such as OneWorld Health (USA), Sekem (Egypt) or Grameen Bank (Bangladesh).

As far as the promotion of, and instruction in, sustainability issues in business school curricula, a major challenge is to change peoples' and institutions' general 'economicideological' ideas and principles. From the perspective of green ecologists, sustainability (pejoratively termed "eco-fascism") means radical changes are required if the world is to survive (Hudson, 2005). From this point of view, business schools, with their support of materialism and capitalism, are the enemy. If radical changes such as Hudson describes were implemented, the logic behind the business model that (most) business schools still promote would lose its support and legitimacy.

However, there is a second and opposing perspective that maintains that technological solutions within existing means of production offer the promise of a trade-off between economic goals and environmental or even social objectives (Hudson, 2005). In this argument, the market in fact is the prime and best mechanism for efficient resource allocation. Business schools will maintain their status quo by continuing to teach the same curricula and the same economic models. This is business as usual; no paradigm shift is needed. Indeed, highly respected researchers, such as Professor Robert Simons (2013) at the Harvard Business School, think business schools have become part of the problem rather than the solution. In his opinion, business schools do not focus enough on what 'the business of the business' really is, namely, to restore a focus on competing to win. This is the traditional focus of market capitalism.

A third perspective lies somewhere in between these two extremes. Proponents of this perspective accept the general legitimacy of markets as mechanisms for resource allocation, but they admit the need for non-Market, State regulation. This perspective suggests that business schools can play an important role as go-between institutions that mediate between the Market and the State. Looking at the current trend, in Western countries at least, it appears that this go-between role may appeal to many academics and academic institutions. It is a role 
that is advantageous to their interests (and possibly is less risky for them). Albert Gore, former US Vice President, Nobel Peace Prize laureate and environmental activist, shares this view. He recommends that business schools teach "sustainable capitalism" as the path to the maximization of long-term economic growth. Such growth requires the integration of environmental, social and governance issues with business strategies, risk assessments and, not least, reward systems. ${ }^{3}$

\section{Sustainability in business schools' curricula}

$B i z E d$, one of the leading magazines in business education in the United States, is an advocate of socially responsible business education (AACSB Exchange, 2011). The magazine and its publisher, the Association to Advance Collegiate Schools of Business (AACSB), are currently investing much time and effort in promoting business sustainability. It is evidence that more business schools are now addressing sustainability issues. For example, in 2007, Bloomberg Business Week published the Aspen Institute's alternative ranking of MBA programmes (at 111 institutions, of which 71 are in the United States). On average, the business schools ranked in the survey offered six electives dedicated to social and environmental issues in their curricula, which was an increase of one elective since the previous inventory taken two years earlier. Of the schools, $63 \%$ required students to take a course on 'business and society issues', and 35\% offered a special concentration in social and environmental issues.

Perhaps somewhat disappointing, however, the same report states that there are few sustainability topics in the core courses of business schools. The schools surveyed stated that professors discussed such issues in only $5 \%$ of core accounting courses and in only $1 \%$ of core finance courses. Unfortunately, not much has changed since 2007. A 2012 ranking by the same institute of 82 top US business schools stated that 'many programs offer little or no course work' in the area of green business and sustainability (Gloeckler, 2013, p. 1).

One reason for the lack of sustainability issues in business school curricula is that university lecturers often do not have a clear understanding of sustainability (Reid and Petocz, 2006). For many lecturers, it seems easier to define non-sustainability than to define sustainability; therefore, they often continue to use business model failures from the past as pedagogic examples. For example, a pedagogic example that many academics and practitioners use is the Enron accounting scandal of 2001. In 2000, one year before the downfall of Enron, Gary Hamel, the admired business thinker and visionary, published his book entitled (in English) Leading the Revolution. In his book, Hamel described how Enron, who recruited the best and brightest MBAs from top-ranked business schools, helped some 'revolutionary organizations' find 'new and creative ways to earn money'. Today, most people understand that some of these Enron MBAs, and especially their bosses, were too creative and lacked a broader perspective on the role of (sustainable) capitalism.

The problem is exacerbated by the fact that many business students are unaware and uninterested in these issues (Reid et al., 2009). Thus, among lecturers and students, there is a great deal of uncertainty, even ignorance, about the meaning, scope, boundaries, application and limitations of the term sustainability that a clearer definition might resolve. However, not everyone agrees. For example, Stuart Hart (2009) resists the call for clearer definitions of sustainability with his claim that such definitions are unduly restrictive.

In other areas, there is consensus that commonly agreed-on standards are needed to understand complex and value-loaded issues (Hart, 2009). For example, in the areas of finance and investment, there are discussions on the issue of ethical funds. Such discussions can be controversial because it is not easy to state what 'ethical' really means. Are investments in clinics that perform abortions ethical? Should investments in nuclear power be classified as ethical (or sustainable)? Similarly, serious discussion about sustainability is needed before change can occur. In business schools, this means implementation of a creative 
pedagogy that acknowledges the different ways people think and talk about sustainability (Reid et al., 2009).

Business and management education must keep up with the demands of today's society. The business models used in practice and taught in business schools, however, do not present a valid and complete picture of how companies should create, deliver and capture value in order to develop sustainable business and to support a sustainable world (see the overview by Novak and Waldier, 2011). In fact, various observers have remarked that today's business school curricula, even at top-ranked business schools around the world, are rather oldfashioned (Pfeffer and Fong, 2004; Colby et al., 2011; Bisoux, 2012). Their traditional pedagogic model rarely features multidisciplinary integration, experimentation, and practical and relevant learning. Several critics have called for radical change. They think business schools should increase their focus on business ethics and corporate social responsibility, provide more in-depth instruction in 'soft skills', teach more information technology skills, and take a broader global perspective (Navarro, 2008).

According to Pfeffer and Fong (2004, pp. 1516-1517), business schools should place stronger emphasis on their professional ethos and 'break free of the ratings game and vocational focus that constrains their ability to provide critical, analytic thought and analysis'. In their view, the business model for business schools must include a real value proposition that promotes new ideas and ideals about the profession of management educators, about management, and about business life in general, all in the context of the sustainable society.

To add more value to society, the prestigious and influential Carnegie Foundation for the Advancement of Teaching advocates a broader and more humanistic view of business school education. This view is consistent with Colby et al.'s (2011) complaint that business school graduates too often think only in a basically instrumentalist way that focuses exclusively on markets and business. The influential AACSB (AACSB, 2011, 2013), in contrast, advocates more cross-disciplinary collaboration, particularly with schools and departments in the natural sciences and engineering. Another proposal calls for more innovative business solutions and improved effectiveness in business school programmes (Bisoux, 2012).

Robert Simons (2013), on the other hand, is critical of (American) business schools in general, and MBA programmes in particular. He thinks business schools are too focused on training students to make analyses in all possible ways without teaching them how to implement such analyses. With others (e.g., Datar et al., 2010; David et al., 2011), Simons advocates less academic rigor and more business relevance. This advocacy is consistent with the views of Tony Wagner, another of today's visionaries, who believes that ' $[t]$ he world no longer cares what you know [...] but about what you can do with what you know' (as quoted in Iannarelli, 2013, p. 1). This ability requires a wise combination of academic rigor and societal relevance in order to have an effect.

When we look at how to achieve this increased professionalism, Simons' and Wagner's positions, however, seem to be rather more ideological than practical, as the concept of sustainability need not be contrary to the concept of making money. Thinking in terms of money-making alone instead of thinking in terms of sustainable capitalism seems narrowminded and fairly old-fashioned though. Indeed, several other Harvard Business School faculty members (see Bower et al., 2011) recommend that CEOs work in the interests of more stakeholders and take a more active role in trying to overcome global threats to capitalism itself (e.g., inequality, global warming, corruption, and weaknesses in the world's financial systems). 


\section{Business models and business practices}

Today, prominent business leaders have begun to talk about the crisis caused by the continued use of yesterday's business models in practice. For example, the managing director of McKinsey \& Company, Dominic Barton, is a critic of 'short-termism and quarterly capitalism' and an advocate of 'long-term capitalism' (McKinsey, 2011). According to Barton, continued growth and a flourishing economy are only possible if we learn to live within rational financial and ecological constraints.

Several CEOs of well-known 'market capitalist' companies (sometimes in the aftermath of their own admitted wrong doing) support these views. Paul Polman, the CEO of Unilever, claims incentives connected to short-term reporting are at the heart of today's financial problems. He argues there must first be an alignment between capital's interests and capitalism. According to Roger Ferguson, President and CEO of TIAA-CREF, the large institutional investor, the system is more wrong than its people (McKinsey, 2011).

Indeed, systems, in the same way as business models and institutions, are only created, maintained and changed by people. New possibilities, particularly those stemming from large innovations, technology advancements and globalization, have created more and more economic value. Ecological and social constraints, however, require that future business models deal not only with possibilities but also with societal boundaries and restrictions.

Today, there is hope, and even conviction, that business corporations, with their vast resources and power, can make major contributions to sustainability. According to the CEOled organization, World Business Council for Sustainable Development (WBCSD, 2010) and its former president, Björn Stigson, 'the green race is on worldwide' and the questions that remain are 'who wants to participate and who is going to win this race'. This 'green race' is on among governments and companies, according to Stigson, because sustainability is now seen as the key driver of innovation. There is a growing recognition that a company's sustainability performance is a measure of its overall management quality. The members of the WBCSD make a powerful business case for combining this company driver with government support for more green innovations and increased green knowledge.

Stigson believes that sustainability requires the biggest investments the world has ever seen. For him, this means massive new business opportunities. Such investments might have begun after the UN summit in Johannesburg in 2002. Instead, Stigson thinks the world has evolved backwards, mainly due to $9 / 11$ and the focus on the Global War on Terrorism.

Most people agree that the key to success in the future, as in the past, is value creation. For a long time, however, the main debate has centred on what kind of value can be created and for whom. Bradfield (2009, p. 375) concludes: '[i]f sustainability is going to take root and thrive in an organization, it has to demonstrate value to the managers and employees and ultimately to consumers'. Bisoux $(2008$, p. 22) states that many important institutions today not only accept the business case for sustainability but also insist that it 'makes sense'. Bisoux argues that ignoring sustainability issues costs too much in terms of 'lost reputation, tarnished brand, higher employee turnover, and diminished consumer loyalty'.

Increasingly, external pressure for sustainable solutions has been exerted on companies and entire industries by legislation, regulations, voluntary codes of practice (e.g., the United Nations Global Compact - UNGC) and other institutional forces (e.g., the WBCSD). According to Stigson, legislative pressure is needed because the market is too slow to drive global change; in fact, he is convinced that the world's leading companies want more legislation and regulation.

Another source of pressure is the changing attitude towards sustainability among employees and managers. These groups no longer see sustainability as merely an optional add-on but rather as a key driver of successful business (Haugh and Talwar, 2010). Yet old 
practices are difficult to change; more knowledge, learning, and training are needed if a new business model is to develop and succeed.

A current awareness in business circles is that companies need help with their business models if they are to integrate and manage sustainability (Arevalo et al., 2011). Peter Bakker, the new president of WBCSD, calls for a 'new operating system' for capitalism that can 'break the lock of business as usual'. Like Simons (2013), Bakker insists that action and implementation are needed because for 40 years there has only been talk (WBCSD, 2012). However, this 'revolution of capitalism, as Bakker (pp. 6 -7) calls it, requires that sustainable performance be 'concrete, measurable, comparable, and linked to the scientific priorities'.

Business reporting is already a complex endeavour. For example, if followed by companies, such standards as the Corporate Social Reporting or Global Reporting Initiative may easily become excessive and very time-consuming. The main concern, however, is that such reporting should be relevant and legitimate and should describe real societal value creation, not just everyday company activities.

\section{The role of a 'typical' business school: The case of Handels}

On October 27, 2010, Albert Gore and Björn Stigson, with others discussants, participated in a seminar at the School of Business, Economics and Law at the University of Gothenburg, or Handels as it is called in western Sweden. The aim of the seminar was, in the aftermath of the recent financial crisis, to discuss a type of capitalism that would maximize sustainable economic growth, namely, sustainable capitalism. Gore encouraged students to keep the discussion alive by challenging their professors and any professional economists they meet to take up these issues. Both he and Stigson emphasised the vital role of business schools in society as a link between the Market and the State. They challenged business schools to develop curricula that feature sustainability as the key to a sustainable world. In accepting that challenge, Handels has made sustainability a top priority in its curriculum.

The following section describes some results of Handels' sustainability journey. The goal is to examine the internal factors that influence business schools' curriculum development with regard to sustainability.

Handels is one of eight faculties at the University of Gothenburg (the University). The University, which is one of northern Europe's largest institutions for higher education, covers most scientific disciplines and is proud of its long tradition of education in environmental issues and sustainable development. As early as 1969, the University offered a course in the environment. In 1993, it was also one of the first higher education institutions worldwide to sign the COPERNICUS charter for sustainable development.

The Swedish Higher Education Act governs the University. In addition, Swedish environmental legislation and environmental certifications under ISO 14001 and EMAS (the Eco-Management and Audit Scheme) have certified the University since 2006. In 2010, environmental issues and sustainable development were main topics in $7.1 \%$ of the University's 1,776 stand-alone courses, and subtopics in $12.7 \%$ of these courses.

Handels was founded as a private business school in 1923. Since 1971, Handels has been part of the University (with independent status between 1986 and 1995). Today, Handels offers instruction in Business Administration, Economics and Law - divided among five departments, four institutes or sections, and a number of research centres and support functions. ${ }^{5}$ In 2011, there were 4,133 full-time students at Handels and 455 staff members (including 109 professors and associate professors, 163 postdoctoral teacher-fellows and other teachers, and 66 doctoral students - referred to here as the Staff).

In part, because of the University's decentralized structure and in part because of its own particular history, Handels has a great deal of independence (e.g., Handels is responsible for 
its staffing. financing, and the quality and development of its programmes). Since August 2009, the stated mission of Handels is 'to develop knowledge and educate creative individuals for the advancement of successful organizations and a sustainable world'.

Handels was the first business school in Sweden to sign the Principles for Responsible Management Education (PRME) initiative, which is inspired by the principles of the United Nations Global Compact (UNGC). The six principles of PRME link rather closely to the efforts of business schools to contribute to a sustainable world. In the spring of 2011, Handels joined the UNGC, thereby committing to its ten principles in the areas of human rights, labour, the environment and anti-corruption. Handels' management team also raised the area of sustainability from a strategic level to a practical level in both education and research. At the practical level, there have been seminars on sustainability issues in education in which the discussions concerned current and future activities.

The following section is an account of information acquired from four sources. The first source is external and internal documentation, mostly WebPages, on the sustainable work at the University and at Handels. This also includes the results from a web survey (Dnr: F8 70/10) on the University's environmental work taken by 2,748 staff members and students (the response rate was $29 \%$ for University staff and $7 \%$ for students, inclusive of 120 Staff at Handels).

The second source is a Bachelor thesis, summarized and translated (from Swedish to English). The author of this article was the thesis supervisor. ${ }^{6}$ The third source is an E-mail survey at Handels. In the survey, approximately 250 active teachers/researchers were asked to comment on their curricular involvement in sustainable education. After the survey, there were personal discussions, small and large seminars, and other meetings to clarify comments and to acquire a more comprehensive, although not all-inclusive, picture of the sustainable work at Handels as well as of the driving and hindering forces related to it.

\section{Results: Curriculum development at Handels}

The survey reveals that, compared to the students, the Staff are much more knowledgeable about sustainability issues (the content and meaning of certifications, policies and activity plans). Students rank their education on sustainable development higher than the teachers do, which may indicate that the teachers are rather self-critical because they know the education could be better. Sustainable development education is perceived as very important by $45 \%$ of the students and by $57 \%$ of staff and researchers. Since the 2006 survey, there has been a substantial increase (on average, about $20 \%$ for all groups) in the percentages for all survey participants who rank sustainable development issues and sustainable development education as "very important" or "important".

Per the survey, the slogan, 'To walk the talk', which refers to sustainable issues, was rated the best way to increase students' engagement in environmental and sustainable development issues (by $65 \%$ of students and Staff). Results of this slogan are visible in practice. For example, Handels has placed about 20 waste sorting containers on campus.

Students ranked "free lectures and theme days" as the second best activity to increase their engagement in sustainable issues whereas Staff ranked the development of more interdisciplinary cooperation second. Surprisingly, $40 \%$ of the women but only $29 \%$ of the men think that "mandatory courses within sustainable development" would be a good activity to increase students' engagement. $58 \%$ of the participants think they have sufficient knowledge of environmental and sustainable issues (64\% of Staff and $49 \%$ of students). Men are more confident of their knowledge about these issues than women $(63 \%$ of the men and $54 \%$ of the women). As far as the goals specified in the activity plans (in 9 areas), $78 \%$ of the participants think such goals are relevant, and $84 \%$ think they are realistic. 
The E-mail surveys and seminars reveal that a large majority of the Staff think there is a clear trend to include sustainability issues in most courses in the near future. However, they are unsure as to what form this work will take, how extensive it will be, who will teach it, and how much academic credit students will receive for it. These are resource and capability issues of some importance, especially because there appears to be inadequate expertise in sustainability issues particularly in the Business Administration Department at Handels. In addition, there appears to be insufficient time and support allocated for preparation of such courses.

There is an increased demand from students at Handels to combine sustainability issues with traditional management and business courses. There is, however, little demand to make sustainability an education specialization. Thus, Handels recently abandoned its "environmental programme", replacing it with one year of elective courses in sustainability. One reason for the change was to give students the opportunity to determine for themselves how to combine sustainability courses with their other studies. A second reason was that the change might make students more employable. Apparently, some students, who had been educated as "environmental managers", were disappointed to learn in job interviews that potential employers did not understand the title of "environmental manager".

Thus, students at Handels think courses in which sustainability issues are combined with traditional core subjects have the most potential value. These courses are taught more frequently at the Master's level although some are taught at the Bachelor's level as well. Because the courses at the Bachelor's level are variously packaged and labelled, their content is not clearly evident to students. This situation has created some confusion for students. The Staff recommend that the courses be described more clearly, using common language in the curricula, beginning with students' acceptance to Handels.

The Staff also think increased funding is needed for the introduction of new courses in sustainability or for the revision of "traditional" courses in order to include more sustainability issues. One justification for the request for additional funding and for the use of outside experts for classroom instruction is to reduce student stress. Too much information provided in a pedagogically insufficient manner increases student stress.

The Staff and students think the course curricula and learning outcomes should provide students with the tools needed to understand the objections to non-sustainability and the potential benefits of sustainability. There is a concern that not all teachers can communicate these objections and benefits. Therefore, it is necessary to provide Staff with pedagogical training so that they can teach sustainability issues.

On the other hand, there are numerous members on Staff who are satisfied with the current level of sustainability work (in instruction and in research). Alternatively, there have been discussions at Handels between Chalmers University of Technology (a private university in Gothenburg) and the University about opening "The Gothenburg School of Environmental and Sustainable Studies (GESS)". This school would attract students from all over the world by providing the best and most comprehensive education possible in the field of sustainable development and the environment. Almost two-thirds of Staff, however, resist the idea because they think such a school would diminish the idea that sustainability should be a part of all education offered by the University.

The major topic of discussion in the seminars following the E-mail survey was that sustainable issues should be integrated in ways that lead to the degree of the Sustainable MBA or its Swedish equivalent. This idea contrasts with the traditional practice of teaching sustainability in bits and pieces in most courses. A degree programme for the Sustainable MBA would require significant development and commitment; it could not be simply a Band Aid stuck on traditional courses. 
The Staff also recommend more cross-disciplinary instruction and more interrelated courses as ways to add sustainable issues to the curricula. The faculty held seminars in this area with eminent visitors, such as Professor David Teece from the Haas School of Business, ${ }^{7}$ in order to promote improved curricula in the disciplines and to connect with practice. Teece recommended a model called the 'dynamic capabilities paradigm/framework' (Teece et al., 1997). This model connects the underlying assumptions of the five disciplines ('mainstream economics', 'marketing', 'organizational behaviour', 'finance' and 'strategy') with the assets modern firms either have or need. With its focus on capturing and strategizing entrepreneurial capabilities, Teece's model tries to bridge the gap between theory and practice by integrating the business school disciplines that, together, help 'sense', 'seize' and 'transform' dynamic capabilities in order to achieve the right strategic fit (Teece, 2010, pp. 23-24).

This idea recalls a previous situation at Handels. In 1997, Handels offered the so-called three-year ICU Bachelor degree programme (Integrated Business Education). In the first two years of the programme, almost all courses integrated two or three subjects (e.g., accounting, finance and business law) in which a practical problem was studied in a comprehensive format. The third year was for subject specialization (e.g., finance or accounting).

However, in 2002, the ICU programme dropped the term "integrated" from its name and returned, in most cases, to traditional instruction (i.e., single discipline courses). By then, people said the abbreviation ICU stood for the "Intensive Care Unit". This was the death knell for a courageous attempt to illustrate more of the complexity of real business life. It was obvious that subject integration required different pedagogical skills as well as dedicated engagement by all teachers. The lessons learned were that such integrated education required additional staff education and training, plus advanced coordination and integration to say nothing of extra resources. The other lesson was that the integrated course approach also required more mature students.

In sum, at the time of this research, Handels had 41 senior researchers/teachers and 26 doctoral students (some $20 \%$ of all Staff) who dealt, explicitly, with sustainability issues in their work. See Table 1 for the categorization of Staff into the seven major departments/research centres. The research survey revealed that some 15 to 20 individuals are engaged in most of the sustainable work at Handels.

\begin{tabular}{|l|c|c|c|}
\hline \multicolumn{1}{c|}{$\begin{array}{c}\text { Department / } \\
\text { Research centre }\end{array}$} & $\begin{array}{c}\text { Senior } \\
\text { researchers/teachers }\end{array}$ & Doctoral students & Total \\
\hline Business Administration & 10 & 6 & 16 \\
\hline Economics & 15 & 15 & 30 \\
\hline Economic History & 4 & - & 4 \\
\hline Law & 2 & 1 & 4 \\
\hline $\begin{array}{l}\text { Human and Economic } \\
\text { Geography }\end{array}$ & 4 & - & 2 \\
\hline $\begin{array}{l}\text { Institute for Innovation } \\
\text { and Entrepreneurship }\end{array}$ & 2 & 2 & 6 \\
\hline $\begin{array}{l}\text { Gothenburg Research } \\
\text { Institute }\end{array}$ & 4 & 26 & 67 \\
\hline Total: & 41 & & 5 \\
\hline
\end{tabular}

Table 1: Researchers/teachers and doctoral students who work with sustainability issues at Handels 


\section{A business school as the intermediary between the Market and the State}

Table 1 reveals that almost half the Staff working with sustainability issues at Handels are in the Economics area. The Environmental Economics Unit (EEU) is an excellent example of how an intermediary functions between the Market and the State. The EEU was founded in 1990, with only one lecturer and a few graduate students. As of 2012, the EEU had four full professors and three associate professors, eight research fellows/postdoctoral students and some fifteen doctoral candidates. In addition, the EEU has four policy advisors and a communications officer.

The distinguishing features of the EEU are its unusual combination of research, teaching and policy outreach, its international collaboration and its high publication activity. Many EEU projects involve collaboration with environmental economists in various countries as well as with researchers in other disciplines (mostly natural scientists such as physicists and biologists, and social scientists such as psychologists and anthropologists).

The EEU has its own "corner" in the Handels' building where most "traditional" business and management Staff are located. This physical distance from others at Handels seems to symbolize EEU's psychic distance from them. In fact, some EEU members think their use of different methodologies and terminologies have created "silos" in which they speak almost a different language than the normal business and management language. Prominent personalities at EEU admit that often it is easier for EEU researchers and teachers to work with the technical and scientific faculties from their own and other universities, including Chalmers, than to cooperate with other researches and teachers at Handels.

Why has this enormous development of the EEU no equivalent in the other business departments at Handels? Numerous Staff believe, and evidence from seminars with practitioners indicates, that the main reason for this lack of development in business administration subjects is that the business sector and its managers experience considerable difficulty when dealing with sustainable development issues. Yet if Handels is to act as the Market-State intermediary at the business and individual (micro) levels, it must commit to an expansion of sustainable education in other subjects, such as finance, management and accounting. Adoption of Teece's dynamic capability model could help achieve this ambition.

On October 10, 2011, some 40 business managers from the Gothenburg region met at Handels in order to discuss the connection between sustainability and management accounting and control. A clear consensus from this one-day seminar was that little is known in practice about this connection. Practitioners, including those from world leading companies, have scant information on how to concretize, measure, compare, and evaluate sustainability issues in their systems and accounts. In particular, their companies' innovation strategies are often inadequate to accommodate the highly complex and uncertain nature of these new demands.

In the more regulated fields (e.g., in the area of emission standards), on the other hand, the need to integrate the goals of innovation and sustainable development is widely acknowledged. The EEU, for example, has helped shape, execute, and evaluate such strategies and their outcome.

\section{Mapping external forces affecting business schools' curriculum change}

Figure 3 presents a tentative model that conceptualizes the major external forces that affect business schools' curriculum change. An internal circuit illustrates the supply and demand in the "Market" for graduates with a sustainability development education. In order for sustainability to take root and thrive in an organization, it has first to demonstrate its value to the organization's managers, employees and customers. If sustainability demonstrates its value and importance to deans, staff and students, business schools will adapt their curricula 
to offer students sustainability education. If sustainability demonstrates its value to organizations and companies, business recruiters will seek graduates who have such education.

The visualization of supply and demand in a circle, which is the typical format used in business schools, demonstrates the potential for business schools in their role as educators. The first mover advantage, or the "not to fall behind" argument, is as valid for business schools pursuing sustainable development as it is for companies on the same quest. The drivers of innovation at companies as well as at business schools need to learn how to develop and use new, and sometimes revolutionary, business models. Business schools should teach students how to implement these models.

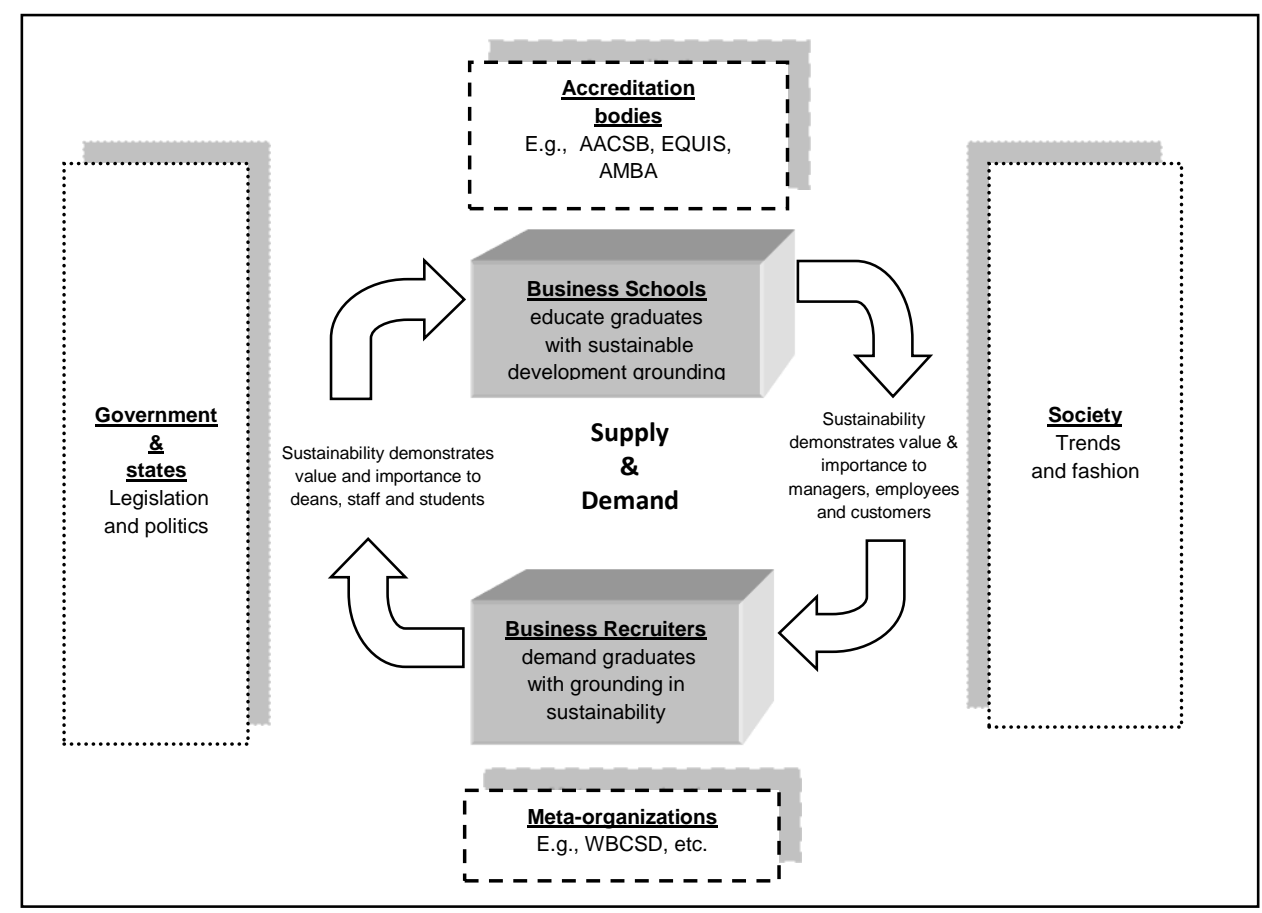

Figure 3: Major external forces affecting business schools' curriculum change

At the top and bottom edges of the supply and demand circle, Figure 3 depicts two boxes: these are the powerful, institutional forces - the accreditation organizations (e.g., AACSB, EQUIS, AMBA, etc.) - and the meta-organizations (e.g., the WBCSD). Figure 3 also shows within the supply and demand circle the close proximity of business schools and their recruiters. Figure 3 shows further the influential proximity of society's trends and fashions and of governmental legislation and politics.

Market-driven innovations, often, are the victims of their time (e.g., the recent financial crisis). The effects on future generations will therefore be marginalized by social and environmental pressures that present additional constraints. Consequently, it-seems evident that sustainable development innovations, if they are to have the same force as market-driven innovations, must consider a wider range of stakeholders, many of whom have contradictory demands.Traditionally, not least after the 1980s and 1990s, business executives have focused on the market and customers while public policymakers have concentrated on societal needs. For sustainable capitalism to establish itself in the business world, business must address the demands and objections from all sides. This approach requires much more intense cooperation between businesses and business schools. Altogether, the continued strong supply of and 
demand for business students, however, will very likely positively influence both the academic rigor and the relevance of business schools.

\section{Mapping internal forces affecting business schools' curriculum change}

Figure 4 presents a tentative model of the major internal forces that influence business schools' curriculum change towards sustainability. Figure 4 depicts these internal forces as a circle formed by four forces: the Students, Management Strategy, Management Support, and Staff. These four forces, in many issues, interrelate rather than exert a unilateral influence. The box 'Students' shows the importance of student involvement in curriculum change at business schools. One way for students to influence the curricula is through their student associations where they are asked to sign contracts when they first enrol. Such contracts could include a "code of conduct" related to present and future ethically responsible behaviour. In their relationships with their students, business schools are recommended to "walk the talk" with their students and with society.

Handels exemplifies the importance of business school Management Support and Management Strategy in bringing about curriculum change. However, its mission and vision of sustainable capitalism are not Handels' main drivers for change. In fact, such change is the result of very considerable efforts by some departments and particularly enthusiastic individuals. The broad focus at Handels is an important explanation for the inclusion of sustainable development issues in its curricula.

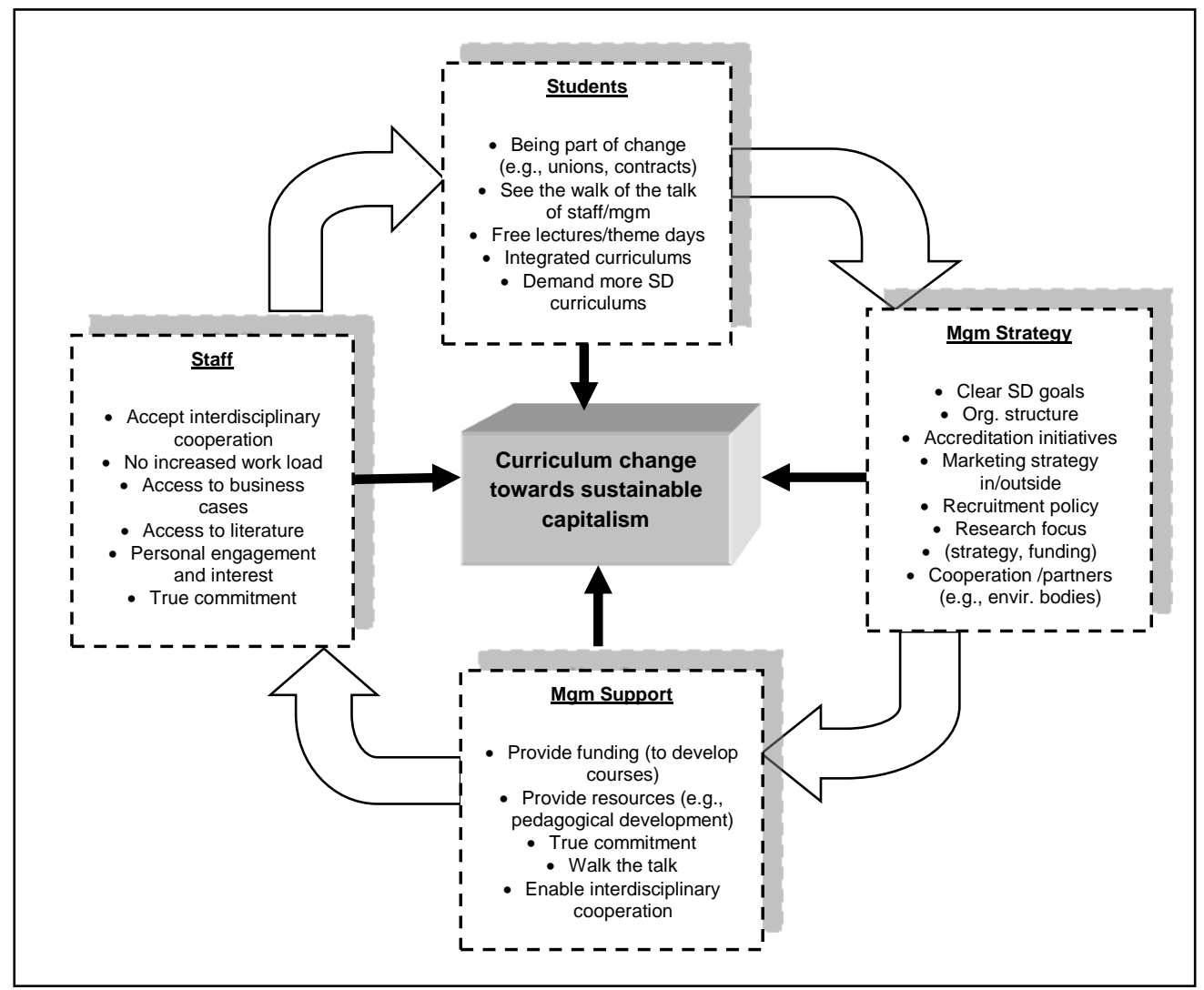

Figure 4: Major internal forces affecting business schools' curriculum change 
Although, the sustainability and environmental courses at Handels focus on traditional, company-related issues, they also examine much broader management and business issues. Even the names of the departments, institutes and centres suggest this wider perspective on the world. Handels today is an ecosystem that reflects the business ideas and interests of many more stakeholders than are typically found in more traditional business schools. Other business schools could learn from this example.

The bottom-up management style at Handels also facilitates its implementation of curricular change. This is the traditional Swedish management style known as "soft leadership" that values team spirit, informality and consensus. (It may be noted that at business schools in other cultural settings, such a management style may encounter challenges.)

At Handels, the Staff's personal engagement in, enthusiasm for, and curiosity about sustainability issues are their strongest tools for bringing about curriculum change. Their research activities are frequently the catalysts for such change. Management's task is to promote those activities by establishing a supportive organizational structure that encourages, among other things, interdisciplinary courses and that assists with research funding. It is also reasonable to assure Staff that they will be compensated in some way for the additional work required to add sustainability issues to their courses.

The majority of Staff should be open to change in the curricula. If only the enthusiasts support such change, there is less chance of success. Strong Staff commitment is needed to gain the interest and trust of the students.

As discussed above, responding to the external pressure to be a "modern business school" and to have an "up-to-date" curriculum means including sustainable issues in the curricula. It is a requirement for business schools that compete for reputation and research funding, as well as for students. Many Staff at Handels think that businesses should include sustainability in their business models. They are convinced that the demand for graduates educated in sustainable capitalism will increase as its business relevance becomes better known. In addition, they think it is the obligation of business schools to train researchers to study sustainability issues using a curriculum that emphasises academic rigor and relevance.

\section{Discussion: Towards a society with sustainable capitalism}

This research is based on a single case study and it should be noted that there is a risk that it does not provide a full account of all actions, ideas and opinions involved in the "sustainable work" at Handels (and by extension, at similar business schools). The analysis and the mapping in the article may therefore seem somewhat limited in their general applicability. The research context of the business school, however, permits drawing conclusions that may apply to a broad class of colleges or departments in higher education. In addition, because the research is supported by significant ideas from the literature, general inferences may be drawn about business school curricula.

Taking this limitation in consideration, the findings show that many researchers, academicians, practitioners and students recognize sustainable development as an important issue in the contemporary business environment and in higher education. Work in the area is in progress with evidence of some good results (e.g., see Slater and Dixon-Fowler, 2010). Although sustainable development has a high profile in some disciplines (e.g., at Handels, in the Economics area), yet, in some respects, sustainable development remains a marginal concern in other quite influential disciplines (e.g., at Handels, accounting, management and finance). While Staff generally agree that students require increased skills in, and more knowledge about, sustainability issues, the way forward is less clear.

Educators and researchers are often role models for students. This is as true in the area of sustainable development as in more traditional areas of instruction. Business school teachers 
best fulfil this role when they feature real life, problem-based learning, close cooperation with businesses in the development of (sustainable) business models and cross-discipline courses (Teece, 2010), and a holistic approach to education (Starkey et al., 2004; Bennis and O'Toole, 2005; Giacalone and Thompson, 2006; Bradfield, 2009; Thomas and Cornuel, 2011). Besides interest and commitment, teachers require special pedagogical skills for this complex task. Consensus policies regarding the need for increased funding for teachers, especially for course administrators, are also essential. As more students request sustainable development courses, there must be a pool of knowledgeable teachers qualified to present these courses.

The development of course materials that satisfy the demands by students, businesses, various other stakeholders and the general public is a time-consuming endeavour in any circumstance. When this work involves all curricula in a modern business school, even more time and effort are required. The work entails rigorous course and curricula reviews, coordination of the various disciplines, and education and training of teachers, to mention only three requirements.

The tasks of business school management, additionally, are to raise awareness of the mission and vision related to sustainability issues, to define the strategies needed to implement that mission and vision, and to support the acquisition of the knowledge and skills needed to pursue these goals. It is also a management task to seek significant investment that will support commitment to such curriculum change. In short, business schools need leaders who can link the mission and vision of sustainable capitalism to the programmes and courses, directly and understandably.

One practical issue concerns whether students should have the opportunity to make their own selection of sustainability courses. The alternative is to offer them programmes with required sustainability courses. This administrative issue sometimes has the unfortunate effect of overshadowing the more strategic issue, which is informing new students about the mission and vision of sustainable capitalism.

A major finding of this study is that sustainability in business school curricula is generally not well developed because the scientific knowledge and practical application of sustainability in the workplace are also not well developed. Difficult problems arise because of the circularity of the supply and demand between business schools and businesses, and because of the uncertainty about whose needs and demands to focus on and how. Ideology has a powerful influence as far as the proposed solutions to these problems (Acs and Phillips, 2002; Seelos and Mair, 2005; Martin and Osberg, 2007; Simons, 2013). These are crucial questions for business schools that cherish the independence that is the right of institutions of higher education. In the best of (academic) worlds, higher education should pioneer and drive change in response to society's demands, but only to the extent that academic freedom is not compromised.

Therefore, ideally, business schools should be ahead of best practice in the business world (leading the revolution), or at minimum, should keep pace with it. The increased complexity of the business environment means that discipline-based curricula are increasingly unable to capture all the elements needed to understand and manage real life problems (Navarro, 2008; Teece, 2010; AACSB, 2011, 2013). In part, this explains why business schools, in many cases, seem to lag behind the fast-changing world of work.

Figures 3 and 4 call this problem to our attention: the tension between academic rigor and real world relevance, or academia versus practice. As previously discussed in this article, there are severe critics of the lack of relevance between business school education and business practice (Pfeffer and Fong, 2002, 2004; Mintzberg, 2004). One complication, faculty shortage, has in recent years resulted in calls for business schools to move towards the more professional model of education. There is, however, fierce resistance in academia (Colby et al., 2011; AACSB, 2011, 2013) to the professionalization of research and instruction that is 
based in the mission of scientific inquiry. It is a fine balancing act between developing curricula that are evaluated by the criteria of employable graduates and developing curricula that are evaluated by the pedagogic and intellectual criteria of discovery and preservation of knowledge.

\section{Conclusion}

In conclusion, (relatively) free market capitalism is an economic philosophy that has, more than any other, benefitted humankind in many places worldwide. This should not be forgotten in the discussion about the future role of business schools. Much of the empirical research and the Handels case illustrate that when business school leaders and course administrators/teachers commit enthusiastically to education in sustainability issues, the opportunities for a conversation about sustainable capitalism increase significantly.

Business schools ought to realize that they have an obligation to integrate issues of sustainability in their programmes and curricula because the return on financial capital alone is not an adequate measure of success: social and natural capital must be included. Teaching the concepts behind sustainable capitalism means preparing leaders and managers for the future and demonstrating that success is measured not only by the amount of profit but also by how the profit is earned.

In summary, the article illustrates that there is a way forward to a real paradigm shift in business school education. Despite the many local victories, however, we have a long way to go before we can talk about systematic and real change in business school education. The conversation has only really begun and more research, looking specifically at supply and demand for truly sustainable business models and practises, and the more precise role of business schools in all this, is needed.

\section{Notes}

1. Sustainable development, as used in this article, refers to development 'that meets the needs of the present without compromising the ability of future generations to meet their own needs' and includes at the same time the three pillars of economic, social and environmental development (WCED, 1987).

2. It is of interest to ask how we define a "business model" in society in general and in business schools in particular. For the purpose of this article, a business model, as a term, describes some heuristic logic that connects different elements purposefully in order to create value. The discussion in the article looks at which elements to include in a business model and at the kinds of value it creates.

3. Albert Gore at a seminar at the School of Business, Economics and Law, the University of Gothenburg, on October 27, 2010.

4. Björn Stigson was Guest Professor at the School of Business, Economics and Law, the University of Gothenburg, from 2010-2012.

5. The five departments are: Business Administration; Economic History; Human and Economic Geography; Economics; and Law. The three institutes or sections are the Gothenburg Research Institute, the Institute for Innovation \& Entrepreneurship, and the 
Graduate School. Handels has major research centres in retailing, tourism, business solutions, business in society, international business studies, regional analysis, globalization and development, and consumer science.

6. The authors of the thesis are D. Vural and N. Ackar (2010). Their empirical data are interviews with directors of studies, E-mail responses from course administrators, and student survey comments from a Master's class.

7. The seminar with David Teece was held on April 12, 2011, on the theme of "Achieving integration of the business school curriculum using the dynamic capabilities framework". 


\section{References}

AACSB Exchange (2011), [Online] Available at: http://theexchange.aacsb.edu/AACSB/AACSB/LinkPage/Default.aspx, [Accessed May $9^{\text {th }}$ 2011].

AACSB Exchange (2013), [Online] Available at: http://www.aacsb.edu/undergraduate-curriculum/, [Accessed Feb 22 ${ }^{\text {nd }} 2013$ ].

Acs, Z., and Phillips, R. (2002), "Entrepreneurship and Philanthropy in American Capitalism", Small Business Economics, Vol. 19, Issue 3, pp. 189-204.

Arevalo, J., Castelló, I, de Colle, S., Lenssen, G., Neumann, K., and Zollo, M. (2011), "Introduction to the special issue: Integrating sustainability in business models", Journal of Management Development, Vol. 30, Issue 10, pp. 941- 954.

Bennis, W.G., and O'Toole, J. (2005), "How business schools lost their way", Harvard Business Review, May 2005.

Bisoux, T. (2008), “The socially responsible curriculum”, BizEd July/August, Vol. 7, Iss. 4, p. 22.

Bisoux, T. (2012), “Collaborative efforts”, BizEd March/April, Vol. 11, Iss. 2, pp. 19-26.

Bower, J.L., Herman, B.L. and Paine, L.S. (2011), "Capitalism at risk: rethinking the role of business", Harvard Business Review Press, Boston.

Bradfield, S. L. (2009), “The value of sustainability education”, Journal of Management Education, Vol. 33, No. 3, pp. 372-375.

Colby, A., Ehrlich, T., Sullivan, W., and Dolle, J. (2011), "Rethinking Undergraduate Business Education - Liberal Learning for the Profession”, Jossey-Bass, San Francisco.

Damast, A. (2007), "Stanford tops sustainability rankings", [Online] Available at: http://www.businessweek.com/bschools/content/oct2007/bs20071010_443096.htm [Accessed June 19 ${ }^{\text {th }}$ 2011].

Datar, S., Garvin, D. A. and Cullen P. G. (2010), "Rethinking the MBA: Business Education at a Crossroads", Harvard Business Press, Boston.

David, F.R., David, M. E. and David, F. R. (2011), "What are business schools doing for business today?", Business Horizons, Vol. 54, pp. 51-62.

den Hond, F. and de Bakker, F.G.A. (2007), "Ideologically motivated activism: how activist groups influence corporate social change activities", Academy of Management Review, Vol. 32, pp. 901-924.

Dnr: F8 70/10a (2010), Sammanställning av svar på webbenkät: "Miljö och hållbar utveckling vid Göteborgs universitet", Göteborgs Universitet. [Online] Available at: www.gu.se/miljo [Accessed Dec 12 $2^{\text {th }} 2010$ ].

Dnr: F8 70/10b. (2010), Handlingsplan för miljö och hållbar utveckling 2011-2015, Göteborgs Universitet, [Online] Available at: www.styrdokument.adm.gu.se and www.gu.se/miljo, [Accessed Jan 20 ${ }^{\text {th }}$ 2011].

European Communities (2009), Conference Proceedings, Beyond GDP - Measuring progress, true wealth and the well-being of nations, 19-20 November 2007, European Parliament 2007, ISBN 978-92-79-09531-3 and available on http://ec.europa.eu/, [Accessed May $13^{\text {th }}$ 2013].

Forray, J. M., \& Leigh, J. S. (2012), “A Primer on the Principles of Responsible Management Education Intellectual Roots and Waves of Change", Journal of Management Education, Vol. 36, Nr. 3, pp. 295-309.

Ghoshal, S. (2005), "Bad management theories are destroying good management practices", Academy of Management Learning and Education, Vol. 4 No. 1, pp. 75-91.

Giacalone, R. A. and Thompson, K. R. (2006), "Business ethics and social responsibility education: Shifting the worldview", Academy of Management Learning and Education, Vol. 5 No. 3, pp. 266-277. 
Gloeckler, G. (2013), “MBA rankings: Top Schools for sustainability”, [Online] Available at: http://www.businessweek.com/articles/2013-01-22/mba-rankings-top-schools-forsustainability\#r=blg-s, [Accessed April 16 ${ }^{\text {th }}$ 2013].

Goodrick, E. (2002), "From management as a vocation to management as a scientific activity: An institutional account of a paradigm shift", Journal of Management, Vol. 28, No. 5, pp. 649-668.

GRLI (2013), "50 + 20 report on the future of business education to be presented at Rio+20 Earth Summit”, [Online] Available at:

http://www.grli.org/index.php/component/content/article/53-latest-news-/248-5020-reporton-the-future-of-business-education-, [Accessed Feb 22 ${ }^{\text {nd }} 2013$ ].

Hailey, J. (1998), "Management education for sustainable development", Sustainable Development, Vol. 6, pp. 40-48.

Hamel, G. (2001), "I spetsen för revolutionen" [Leading the revolution], original work published in 2000 by Harvard Business School Press), Svenska Förlaget, Stockholm.

Hart, S. (2009), “Converging on green”, BizEd July/August, Vol. 8, Iss. 4, pp. 24-28.

Haugh, H. and Talwar, A. (2010), How do corporations embed sustainability across the organization? Academy of Management Learning and Education, Vol. 9 No. 3, pp. 384396.

Henle, C.A. (2006), "Bad apples or bad barrels? A former CEO discusses the interplay of person and situation with implications for business education", Academy of Management Learning and Education. Vol. 5 No. 3, pp. 346-355.

Holland, K. (2009), "Is it time to retrain B-schools?", New York Times, March 15 ${ }^{\text {th }}, 2009$.

Hudson, R. (2005), "Towards sustainable economic practices, flows and spaces: Or is the necessary impossible and the impossible necessary"? Sustainable Development, Vol. 13, pp. 239-252.

Iannarelli, J., (2013), "Plenary speakers inspire business school leaders to focus on choice, culture, and curricula', eNewsline, [Online] Available at: http://www.aacsb.edu/enewsline/speakers-inspire-b-school-leaders.asp, [Accessed April $\left.16^{\text {th }} 2013\right]$.

Lambert, R. (2012), “What does business want from business schools”? Global Focus Magazine, [Online] Available at: http://www.efmd.org/index.php/global-focus/globalfocus-magazine [Accessed November $3^{\text {rd }}, 2012$ ].

Lazonick, William and O'Sullivan, Mary (2000), "Maximizing shareholder value: a new ideology for corporate governance", Journal of Economy and Society, Vol. 29, No. 1, pp. 13-35.

Martin, R.L., and Osberg, S. (2007), "Social Entrepreneurship: The case for definition", Stanford Social Innovation Review, spring 2007.

McKinsey (2011), "Long-term capitalism", [Online] Available at: http://www.mckinsey.com/Capitalism/Roger_Ferguson.aspx, [Accessed May 12 ${ }^{\text {th }} 2011$ ].

Mintzberg, H. (2004), Managers not MBAs: A Hard Look at the Soft Practice of Managing and Management Development, Berrett-Koehler Publishers, San Francisco.

Navarro, P. (2008), "The MBA core curricula of top-ranked U.S. business schools: A study in failure"? Academy of Management Learning and Education. Vol. 7 No. 1, pp. 108-123.

Novak, A. and Waldier, J. (2011), "Business model advisory panel meeting - Business model literature overview", European Financial Reporting Advisory Group (EFRAG), BMAP Meeting, October 17-21, 2011.

Olssen, M. and Peters, M. A. (2005), "Neoliberalism, higher education and the knowledge economy: from the free market to knowledge capitalism", Journal of Education Policy, Vol. 20, No. 3, pp. 313-345. 
Pfeffer, J. and Fong, C. T. (2002), "The end of business schools? Less success than meets the eye", Academy of Management Learning and Education. Vol. 1 No. 1, pp. 78-95.

Pfeffer, J. and Fong, C. T. (2004), "The business school 'business': Some lessons from the US experience", Journal of Management Studies, Vol. 41 No. 8, pp. 1501-1520.Porter, M. E. and Kramer, M. R. (2011), "Creating shared value”, Harvard Business Review, Vol. 89, pp. 62-66.

Prahalad, C. K. (1994). "Corporate Governance or Corporate Value Added?: Rethinking the Primacy of Shareholder Value". Journal of Applied Corporate Finance, Vol. 6, No. 4, p. 40.

Rappaport, Alfred (1986). Creating shareholder value: The new standard for business performance. Free Press, New York.

Reid A. and Petocz, P. (2006), “University lecturers' understanding of sustainability”. Higher Education, Vol. 51, pp. 105-123.

Reid, A, Petocz, P. and Taylor, P. (2009), "Business students' conception of sustainability". Sustainability, Vol. 1 No. 3, pp. 662-673.

Scherer, A. G., Palazzo G. and Seidl, D. (2013), "Managing legitimacy in complex and heterogeneous environments: Sustainable Development in a globalized world". Journal of Management Studies, Vol. 50 No. 2, pp. 259-284.

Simons, R. (2013), "The business of business school: Restoring a focus on competing to win", Capitalism and Society, Vol. 8, Iss. 1, Article 2, pp. 1-37.

Seelos, C. and Mair, J. (2005), "Social entrepreneurship: Creating new business models to serve the poor", Business Horizons, Vol. 48, pp. 241-246.

Slater, D. J. and Dixon-Fowler, H. R. (2010), "The future of the planet in the hands of MBAs: An examination of CEO MBA education and corporate environmental performance", Academy of Management Learning and Education. Vol. 9 No. 3, pp. 429-441.

Starkey, K., Hatchuel, A. and Tempest, S. (2004), "Rethinking the business school". Journal of Management Studies, Vol. 41 No. 8, pp. 1521-1531.

Teece, D. J., Pisano, G. and Shuen, A. (1997), "Dynamic capabilities and strategic management", Strategic Management Journal, Vol. 18, No. 7, pp. 509-533.

Teece, D. (2010), "Achieving integration of the business school curriculum using the dynamic capabilities framework", Draft v8, May 3, 2010, paper presented at the School of Business, Economics and Law at Gothenburg University, April, 12 $2^{\text {th }}, 2011$.

Thomas, H. and Cornuel, E. (2011), "Business school futures: Evaluation and perspectives". Journal of Management Development, Vol. 30 No. 5, pp. 444-450.

Vural, D. and Ackar, N. (2010), Handelshögskolans hållbarhetsintegrering - en undersökning om hur Handelshögskolan vid Göteborgs universitet integrerar hållbar utveckling i sitt kursutbud. Bachelor thesis, Gothenburg University.

WBCSD (2010), "The green race is on. The new business agenda". World Business Council for Sustainable Business' Annual Review 2009. [Online] Available at: http://www.wbcsd.org/Plugins/DocSearch/details.asp?DocTypeId=25andObjectId=Mzgw NTc [Accessed April $4^{\text {th }} 2011$ ].

WBCSD (2012), “Peter Bakker keynotes at Prince's Accounting for Sustainability Project annual [Online] Available at: http://www.wbcsd.org/Pages/eNews/eNewsDetails.aspx?ID=15305\&NoSearchContextKey $=$ true [Accessed April 16 ${ }^{\text {th }}$ 2013].

WCED (1987), World Commission on Environment and Development, "Our Common Future”, Oxford University Press, Oxford. 
